\title{
Loss of balance and fall risk, and their relationship with disease activity, functional status, spinal mobility, quality of life and enthesitis score in patients with ankylosing spondylitis: A cross- sectional study
}

\section{Ankilozan spondilit'li hastalarda denge kaybı ve düşme riskinin hastalık aktivitesi, fonksiyonel durum, spinal mobilite, yaşam kalitesi ve entezit skoru ile ilişkisi: Kesitsel bir çalışma}

\author{
Mehmet Ozan Bingo̊l1, Ahmet Karadağ
}

${ }^{I}$ Department of Physical Medicine and Rehabilitation, Faculty of Medicine, Sivas Cumhuriyet University, Sivas, Turke

Corresponding author: Ahmet Karadağ, MD, Department of Physical Medicine and Rehabilitation, Faculty of Medicine, Sivas Cumhuriyet University, Sivas, Turkey.

E-mail: dr ahmetkaradag@hotmail.com

Received/Accepted: November 01, 2020 / December 08, 2020

Conflict of interest: There is not a conflict of interest

\section{SUMMARY}

Objective: This study evaluates the loss of balance and fall risk in patients with Ankylosing Spondylitis (AS), and assesses their relationship with disease activity, functional status, spinal mobility, quality of life and enthesitis score.

Method: Included in the study were 50 AS patients who were diagnosed in accordance with the modified New York criteria, and 50 healthy volunteers of similar age and gender. For the AS patients, disease activity was assessed using the Bath Ankylosing Spondylitis Activity Index (BASDAI) and Ankylosing Spondylitis Disease Activity Score (ASDAS) C-reactive protein/Erythrocyte sedimentation rate (CRP/ESR); functional status was assessed using the Bath Ankylosing Spondylitis Functional Index (BASFI); spinal mobility was assessed using the Bath Ankylosing Spondylitis Metrology Index (BASMI); and quality of life was assessed using the Ankylosing Spondylitis Quality of Life Questionnaire (ASQoL). Additionally, a Short form-36 (SF-36) was used to assess quality of life in both the AS patients and the healthy control group; while a Timed Up and Go-test (TUG), Functional Reach Test (FRT), Berg Balance Scale (BBS) and Tinnetti's Falls Efficacy Scale (TFES) were used to assess balance and fall risk. Enthesitis in the AS patients was evaluated using Maastricht Ankylosing Spondylitis Enthesitis Score (MASES).

Results: A comparison of the AS patients and the healthy controls in terms of BBS, FRT, TUG and TFES revealed balance loss and fall risk to be higher in the AS patient group, to a statistically significant degree $(\mathrm{p}<0.001)$. BBS, FRT, TUG and TFES were statistically significantly correlated with BASDAI, BASMI, BASFI, ASDAS-ESR, ASDAS-CRP and ASQoL in AS patients $(\mathrm{p}<0.05)$, while no statistically significant
Mehmet Ozan Bingöl

Ahmet Karadağ

ORCID IDs of the authors: M.O.B. 0000-0001-8723-5264 A.K. $\quad 0000-0002-5284-2256$ 
correlation was identified between BBS, FRT, TUG, TFES and MASES ( $>>0.05)$.

Conclusions: Loss of balance and fall risk are higher in AS patients than in healthy individuals. Loss of balance and fall risk is associated with disease activity, poor functional status, limited spinal mobility and quality of life in AS patients. That said, there is no association between enthesitis score and loss of balance and fall risk in AS patients. These findings suggest that loss of balance loss and fall risk should be assessed in patients with AS.

Keywords: Enthesitis, fall, balance, ankylosing spondylitis

ÖZET

Amaç: Bu çalışmanın amacı Ankilozan Spondilit'li (AS) hastalarda denge kaybı ve düşme riskini değerlendirmek, denge kaybı ve düşme riskinin hastalık aktivitesi, fonksiyonel durum, spinal mobilite, yaşam kalitesi ve entezit skoru ile ilişkisini araştırmaktır.

Yöntem: Bu çalışmaya modifiye New York kriterlerine göre tanı alan 50 AS'li hasta, yaş ve cinsiyet açısından benzer 50 sağlıklı gönüllü dahil edildi. AS’li hastalarda hastalık aktivitesini değerlendirmek için Bath Ankilozan Spondilit Aktivite İndeksi (BASDAI) ve Ankilozan Spondilit Hastalı Aktivite Skoru (ASDAS) C-reaktiv protein/Eritrosit Sedimentasyon Hızı (CRP/ESH), fonksiyonel durumu değerlendirmek için Bath Ankilozan Spondilit Fonksiyonel İndeks (BASFI), spinal mobiliteyi değerlendirmek için Bath Ankilozan Spondilit Metroloji İndeks (BASMI), yaşam kalitesini değerlendirmek için Ankilozan Spondilit Yaşam Kalitesi Anketi (ASQoL) kullanıldı. Ek olarak AS'li hasta ve sağlıklı kontrol grubunda yaşam kalitesini değerlendirmek için Kısa form-36 (SF-36), dengenin ve düşme riskinin değerlendirmesinde Berg Denge Ölçeği (BBS), Fonksiyonel Erişim Testi (FRT), Zamanlı Kalk Ve Yürü Testi (TUG) ve Tinetti Düşme Etkinlik Ölçeği (TFES) kullanıldı. AS'li hastalarda entezit değerlendirilmesi için Maastricht Ankilozan Spondilit Entezit Skoru (MASES) kullanıldı.

Bulgular: AS'li hastalar ve sağlıklı kontrol grubu BBS, FRT, TUG ve TFES açısından karşılşatırıldığında denge kaybı ve düşme riski AS'li hastalarda daha yüksekti ve bu istatistiksel olarak anlamlıydı ( $p<0.001)$. AS'li hastalarda BBS, FRT, TUG ve TFES ile BASDAI, BASMI, BASFI, ASDAS-ESR, ASDAS-CRP ve ASQoL arasinda istatistiksel olarak anlamlı korelasyon mevcutken $(\mathrm{p}<0.05)$ AS'li hastalarda BBS, FRT, TUG ve TFES ile MASES arasında istatistiksel olarak anlamlı bir korelasyon yoktu $(\mathrm{p}>0.05)$.

Sonuç: AS'li hastalarda denge kaybı ve düşme riski sağlıklı bireylerden daha yüksektir. AS'li hastalarda denge kaybı ve düşme riski ile yüksek hastalık aktivitesi, kötü fonksiyonel durum, kısıtlı spinal mobilite ve yaşam kalitesi arasında bir ilişki vardır. Bununla birlikte AS'li hastalarda entezit skoru ile denge kaybı ve düşme riski arasında ilişki yoktur. Bu sonuçlar AS'li hastalarda denge kaybı ve düşme riskinin değerlendirilmesi gerektiğini göstermiştir.

Anahtar sözcükler: Entezit, düşme, denge, ankilozan spondilit.

\section{INTRODUCTION}

Ankylosing spondylitis is an inflammatory disease that causes structural deformities and functional impairments, affecting specifically the axial skeletal system and leading to back pain and enthesitis. ${ }^{1,2}$ The inflammation and structural deformities associated with AS lead to back pain, spinal stiffness and limitations of movement. ${ }^{3}$ In the advanced stages, AS leads to kyphotic posture and limits the spinal mobility. ${ }^{3}$ The increased kyphosis of the spine in patients with AS causes the balance point to move anteriorly and inferiorly. ${ }^{4}$ Biomechanical changes in AS patients, such as impaired posture and reduced spinal mobility, have been reported to result in balance disorders. ${ }^{3}$ It is known that AS patients are at greater risks of falls fall and have difficulty in maintaining postural stability due to balance disorders. ${ }^{5,6}$
Enthesitis refers to inflammation of the sites where ligaments or tendons attach to the bone. Enthesitis may occur in various parts of the body, but especially in the Achilles region. ${ }^{7}$ Enthesopathies are believed to affect the afferent nerve fibers in the tendons, joints and ligaments, and contribute to a loss of balance by impairing proprioception. $^{8}$

Literature contains a limited number of studies evaluating loss of balance and fall risk in AS patients. That said, to our knowledge, there has yet to be any study evaluating the relationship between enthesitis score with loss of balance and fall risk in patients with AS. The aim of the present study, therefore, is to compare the loss of balance and fall risk in AS patients with healthy subjects, and to identify the association of loss of balance and fall risk with enthesitis score in patients with AS. 


\section{MATERIAL AND METHODS}

This cross-sectional comparative study was conducted in the Physical Medicine and Rehabilitation Clinic between April 2019 and October 2019.

The study included 50 patients aged between 18 and 65 who had been diagnosed with AS according to the modified New York criteria ${ }^{9}$, while the control group included 50 healthy subjects matched for sex, age and body mass index. Hospital staff volunteered to take part as the healthy controls.

Patients with known vestibular or visual problems that could cause balance and posture disorders; those with orthopedic or neurological diseases (hemiplegia, Parkinson's disease, multiple sclerosis, myopathy, scoliosis, extremity amputation, peripheral nerve damage of lower extremities, polyneuropathy, etc.); those with psychiatric diseases, cardiovascular diseases, diabetes and cognitive problems; and those who were pregnant were excluded from the study.

The demographic data of the AS patient group and the healthy controls were recorded. The duration of disease and history of medication of AS patients were questioned, and a detailed musculoskeletal system examination was made by the same physician for each participant. CRP and ESR were analyzed using standard laboratory techniques. The disease activity of the AS patients was assessed using BASDAI ${ }^{10,11}$ and ASDAS-CRP/ESR. ${ }^{12}$ The functional status and spinal mobility of the AS patients were assessed using BASFI ${ }^{13,14}$ and BASMI ${ }^{15}$, respectively. The quality of life of the AS patients was assessed with the ASQoL ${ }^{16,17}$, and in both the AS patients and the healthy controls with SF-36. ${ }^{18,19}$ Finally, BBS, FRT, TUG and TFES ${ }^{20-23}$ were used to assess loss of balance loss and fall risk.

An assessment of enthesitis in the AS patient group was made using MASES, which is an index that evaluates through the palpitation method 13 different enthesitis sites, being the bilateral first costochondral joint, the seventh costochondral joint, the spina iliaca anterior and posterior, the spina iliaca posterior superior, the iliac crests, the Achilles tendon and the fifth lumbar spinous process. The total score varies between 0 and $13 .^{24}$ The musculoskeletal system examination and all assessments of the AS patients were performed in the afternoon to circumvent any problems related to morning stiffness.

The Ethics Committee of Sivas Cumhuriyet University approved the study (number: 2019/03-
20, dated 16.03.2019), and the informed consent of the patients for participation was obtained. This study was conducted in accordance with the Declaration of Helsinki.

\section{Statistical Analysis}

The garnered data was analyzed statistically using IBM SPSS Statistics version 22.0 software (IBM Corp., Armonk, NY, USA). The conformity of the data to normal distribution was analyzed with a Kolmogorov-Smirnov test. A Student's t-test was applied when the parametric test assumptions were met; and a Mann-Whitney U test and Spearman's correlation test was used when the parametric test assumptions could not be met. A correlation of 0.10 to 0.29 was considered slight, 0.30 to 0.49 modest, and 0.50 to 1.0 as good to interpret the results. A ChiSquare test was used to evaluate the categorical data. The data was expressed in tables as numbers, percentages and mean/median \pm standard deviation, with a $\mathrm{p}$ value of $<0.05$ considered statistically significant. Considering the $0.49 \%$ prevalence rate of AS in Turkey ${ }^{2}$ and the total population of the province, 50 patients were included in the study within a $95 \%$ confidence interval. The power of the study was calculated post-hoc and found to be $98.1 \%$.

\section{RESULTS}

Table 1 presents the demographic data of the AS patient group and the healthy control group. Table 2 presents the duration of disease, and the ASDAI, BASMI, BASFI, ASDAS ESR/CRP, ASQoL and MASES values of the AS patient group. A comparison of the results of the BBS, FRT, TUG and TFES assessments of balance loss and fall risk among the AS patients and the healthy control group revealed loss of balance loss and fall risk to be higher in the AS patient group, to a statistically significant degree $(p<0.001)$. Additionally, when the groups were compared in term of quality of life, a statistically significant difference was noted in all subparameters of SF-36 between the AS patients and the control group $(\mathrm{p}<0.001)$ (Table 3$)$. The BBS, FRT, TUG and TFES results, which are used to assess the loss of balance and risk of fall in AS patients, were statistically significantly correlated with BASDAI, BASMI, BASFI, ASDAS-ESR, ASDAS-CRP, ASQoL and SF-36 $(p<0.05)$, while there was no statistically significant correlation between BBS, FRT, TUG, TFES and MASES ( $p>0.05$ ) (Table 4). MASES had a statistically significantly positive correlation with BASDAI, ASDAS-ESR and ASDAS-CRP, pointing to disease activity in AS 
patients $(\mathrm{p}<0.001, \mathrm{r}=0.551 ; \mathrm{p}=0.001, \mathrm{r}=0.414$

$\mathrm{p}=0.001, \mathrm{r}=0.421$, respectively).

Table 1: Comparison of the demographic data of the groups

\begin{tabular}{|lccc|}
\hline & AS patients $(\mathrm{n}=50)$ & Control $(\mathrm{n}=50)$ & \\
\hline & Mean \pm SD & Mean \pm SD & $\mathrm{p}$ \\
Age (year) & $41.50 \pm 9.41$ & $41.38 \pm 9.23$ & 0.929 \\
BMI $\left(\mathrm{kg} / \mathrm{m}^{2}\right)$ & $26.9 \pm 4.18$ & $26.03 \pm 3.74$ & 0.537 \\
Gender & $\mathrm{n}(\%)$ & $\mathrm{n}(\%)$ & \\
Female & $16(32)$ & $16(32)$ & \\
Male & $34(68)$ & $34(68)$ & \\
& & & \\
\hline
\end{tabular}

AS: Ankylosing spondylitis; BMI: Body mass index; n: Number of patients

Table 2: Duration of disease, disease activity scores, spinal mobility, functional status, quality of life and enthesitis score of patients with ankylosing spondylitis

\begin{tabular}{|ll|}
\hline & AS patients $(\mathrm{n}=50)$ \\
\hline & Mean \pm SD \\
Disease duration (year) & $8.2 \pm 6.4$ \\
BASDAI & $5 \pm 1.63$ \\
BASMI & $4.48 \pm 2.46$ \\
BASFI & $5.32 \pm 2.02$ \\
ASDAS-ESR & $2.65 \pm 0.77$ \\
ASDAS-CRP & $2.96 \pm 0.76$ \\
ASQoL & $10.26 \pm 5.16$ \\
MASES & $2.1 \pm 2.13$ \\
\hline
\end{tabular}

AS: Ankylosing spondylitis; BASDAI: Bath Ankylosing Spondylitis Activity Index; BASMI: Bath Ankylosing Spondylitis Metrology Index; BASFI: Bath Ankylosing Spondylitis Functional Index; ASDAS: Ankylosing Spondylitis Disease Activity Score; ESR: Erythrocyte Sedimentation Rate; CRP: C-reactive protein; MASES: Maastricht Ankylosing Spondylitis Enthesis Score; ASQoL: Ankylosing Spondylitis Quality of Life Questionnaire 
Table 3: Comparison of the groups in terms of loss of balance, fall risk and quality of life

\begin{tabular}{|lllr|}
\hline \multicolumn{1}{|c}{ AS $(\mathrm{n}=50)$} & Control $(\mathrm{n}=50)$ & \\
\hline & Mean/Median \pm SD & Mean/Median \pm SD & $p$ \\
Berg Balance Scale & $46.8 \pm 4.99$ & $55.16 \pm 1$ & $<0.001^{*}$ \\
Functional Reach Test & $22.06 \pm 5.73$ & $30.9 \pm 3.22$ & $<0.001^{*}$ \\
Timed Up and Go & $12.5 \pm 3.05$ & $8.82 \pm 1.41$ & $<0.001^{*}$ \\
Tinnetti's Falls Efficacy Scale & $45.4 \pm 19.43$ & $13.04 \pm 4.82$ & $<0.001^{*}$ \\
SF-36 Sub-scales & & & \\
Physical functioning & $59.6 \pm 25.23$ & $90.3 \pm 15.53$ & $<0.001^{*}$ \\
Physical role limitations & $22.5 \pm 35.8$ & $80 \pm 34.63$ & $<0.001^{*}$ \\
Emotional role limitations & $39.34 \pm 42.43$ & $79.34 \pm 33.6$ & $<0.001^{*}$ \\
Vitality & $28.2 \pm 16.93$ & $63 \pm 17.58$ & $<0.001^{* *}$ \\
Mental health & $48.48 \pm 14.98$ & $69.28 \pm 12.56$ & $<0.001^{* *}$ \\
Social functioning & $50.75 \pm 20.27$ & $85 \pm 18.56$ & $<0.001^{*}$ \\
Pain & $46.14 \pm 16.81$ & $77.25 \pm 22.99$ & $<0.001^{* *}$ \\
General health perception & $31.6 \pm 20.81$ & $72.3 \pm 17.76$ & $<0.001^{*}$ \\
& & & \\
\hline
\end{tabular}

AS: Ankylosing spondylitis; SF-36: Short Form-36; n: number of patients; *Mann-Whitney U test was used; **Student's t-test was used.

Table 4: Correlation between BBS, FRT, TUG and TFES and spinal mobility, functional status, disease activity, quality of life and enthesitis score in AS patients

\begin{tabular}{|lcccccccccc|}
\hline \multicolumn{1}{|c}{ AS patients $(\mathrm{n}=50)$} & \multicolumn{1}{c}{ BBS } & \multicolumn{2}{c}{ FRT } & \multicolumn{2}{c}{ TUG } & \multicolumn{2}{c|}{ TFES } \\
\hline & $\mathrm{r}$ & $\mathrm{p}$ & $\mathrm{r}$ & $\mathrm{p}$ & $\mathrm{r}$ & $\mathrm{p}$ & $\mathrm{r}$ & $\mathrm{p}$ \\
MASES & 0.193 & 0.089 & -0.049 & 0.367 & 0.074 & 0.306 & -0.164 & 0.128 \\
BASDAI & -0.28 & 0.024 & -0.351 & 0.006 & 0.370 & 0.004 & 0.241 & 0.046 \\
BASMI & -0.893 & $<0.001$ & -0.523 & $<0.001$ & 0.555 & $<0.001$ & 0.859 & $<0.001$ \\
BASFI & -0.760 & $<0.001$ & -0.613 & $<0.001$ & 0.670 & $<0.001$ & 0.767 & $<0.001$ \\
ASDAS-ESR & -0.426 & 0.001 & -0.429 & 0.001 & 0.479 & $<0.001$ & 0.376 & 0.004 \\
ASDAS-CRP & -0.426 & 0.001 & -0.460 & $<0.001$ & 0.447 & 0.001 & 0.403 & 0.002 \\
\hline
\end{tabular}




\begin{tabular}{|lcccccccc|}
\hline ASQoL & -0.427 & 0.001 & -0.548 & $<0.001$ & -0.500 & $<0.001$ & -0.410 & 0.002 \\
SF-36 & 0.543 & $<0.001$ & 0.524 & $<0.001$ & -0.494 & $<0.001$ & -0.503 & $<0.001$ \\
Disease duration(year) & -0.336 & 0.009 & -0.280 & 0.024 & 0.103 & 0.238 & 0.335 & 0.009 \\
\hline
\end{tabular}

AS: Ankylosing spondylitis; BASDAI: Bath Ankylosing Spondylitis Activity Index; BASMI: Bath Ankylosing Spondylitis Metrology Index; BASFI: Bath Ankylosing Spondylitis Functional Index; ASDAS: Ankylosing Spondylitis Disease Activity Score; ESR: Erythrocyte Sedimentation Rate; CRP: C-reactive protein; MASES: Maastricht Ankylosing Spondylitis Enthesis Score; ASQoL: Ankylosing Spondylitis Quality of Life Questionnaire; BBS: Berg Balance Scale; FRT: Functional Reach Test; TUG: Timed Up and Go-test; TFES: Tinnetti's Falls Efficacy Scale; SF-36: Short form-36, n: number of patients. Spearman correlation test was used.

\section{DISCUSSION}

The present study has evaluated the relationship between loss of balance and fall risk with spinal mobility, functional status, disease activity, quality of life and enthesitis score in patients with AS, and found loss of balance and fall risk to be higher in AS patients than in the healthy control. Furthermore, this study identified an association between loss of balance and fall risk and spinal mobility, functional status, disease activity and quality of life in patients with AS. In contrast, no relationship could be found between loss of balance loss and fall risk, and the enthesitis score.

AS is a chronic progressive inflammatory disease, AS is likely to affect quality of life through functional restrictions. Previous clinical studies have demonstrated that quality of life is affected in AS patients ${ }^{26,27}$ In the present study, all sub parameters of SF-36, as an evaluation of quality of life, were found to be lower in AS patients than in healthy controls. This finding concurs with previous studies evaluating quality of life in AS. Patients with AS are likely to experience abnormal postural changes during the course of the disease, and these have been reported to have a negative effect on balance. Murray et al. ${ }^{28}$ identified a greater loss of balance in AS patients than in the healthy controls. Likewise, studies evaluating balance through various methods in the presence of AS showed a higher extent of balance loss in AS when compared to healthy subjects. ${ }^{29-31}$ Similar to prior clinical studies, the findings of the present study showed that AS patients experienced a greater loss of balance than healthy subjects. Poor balance is a significant risk factor for falls. Despite various clinical studies assessing loss of balance in AS patients, there have been limited studies evaluating the risk of falls in AS patients. Dursun et al. ${ }^{5}$ identified a greater risk of falls in AS patients when compared to healthy subjects; and another study also demonstrated a greater risk of falls in AS patients compared to healthy subjects. ${ }^{32}$ Furthermore, previous clinical studies have reported an association between risk of falls and duration of disease, BASMI, BASDAI, BASFI and ASQoL scores that measure spinal mobility, functional status, disease activity and quality of life. ${ }^{5,32}$ Similar to previous clinical studies, the findings of the present study indicate that AS patients are at greater risk of falls than healthy subjects. Similar to the findings of previous clinical studies, it is demonstrated in the present study that spinal mobility, functional status, disease activity and quality of life are associated with risk of falls in AS patients.

Enthesitis is a significant clinical symptom of AS, referring to inflammation in the areas where ligaments or tendons attach to the bone. ${ }^{33}$ Enthesitis has been linked to disease activity in AS. One clinical study established a link between BASDAI, which indicates disease activity in AS, and enthesitis indices. ${ }^{27,34,35}$ The findings of the present study are in agreement with earlier studies, showing a significant correlation between enthesitis score and the BASDAI disease activity index in AS patients. Furthermore, the present study further established that ASDAS-CRP and ASDAS-ESR, which indicate disease activity differently from BASDAI in AS, were significantly correlated with enthesitis score.

Entheses are believed to impair proprioception by affecting the nerve fibers and Golgi tendon organs, resulting in loss of balance. ${ }^{8}$ Previous studies have reported that Achilles enthesitis in particular has an adverse effect on balance in AS. ${ }^{8,33}$ A recent study by Talu et al. ${ }^{8}$ identified an association between high MASES values and high postural sway in AS patients. The present study found no link between enthesitis score and loss of balance in AS patients. The findings of the present study are different to those reported in previous clinical studies, which we believe may be due to the differences in methods used for the evaluation of balance disorders in AS. To our knowledge, this study is the first to assess the link between enthesitis score and risk of falls in AS patients, and concluded that no 
significant association exists between enthesitis score and risk of falls in AS patients.

In addition to the methods used, the limitations of this study include the lack of evaluation of loss of balance and risk of fall for device assisted, its lack of separation of patients into drug users and nonusers (the drug be potentially vestibulotoxic), its lack of evaluation of Mander enthesis index, its lack of distinction between peripheral involvement and axial involvement in AS patients, its failure to question the history of falls of AS patients, and its failure to use ultrasound or magnetic resonance imaging to detect the presence of enthesitis.

In conclusion, this study has demonstrated that loss of balance and risk of fall is higher in AS patients than in healthy individuals. The study also revealed loss of balance and risk of fall to be significantly associated with disease activity, poor functional status, limited spinal mobility and quality of life in AS patients. No association was identified between the enthesitis score and loss of balance and risk of falls in AS patients. We believe that these findings will raise awareness of physicians during the treatment and follow-up of AS patients regarding the assessment of loss of balance loss and risk of fall. There is a need for further clinical studies to objectively evaluate the loss of balance and risk of falls involving a larger number of patients, with imaging techniques used to assess enthesitis.

\section{Declaration of conflicting interests}

The authors declared no conflicts of interest with respect to the authorship and/or publication of this article

\section{Funding}

None

\section{REFERENCES}

1. Hayta E, Karadağ A, Gumus C. Tetraplegia developing with skull traction in patients with ankylosing spondylitis (AS): A case report. Int $\mathbf{J}$ Case Rep Images 2016;7:111-114.

2. Koca TT, Göğebakan H, Koçyiğit BF, Nacitarhan V, Yildir CZ. Foot functions in ankylosing spondylitis. Clin Rheumatol 2019;38:1083-1088.

3. Acar Y, Ilçin N, Gürpinar B, Can G. Core stability and balance in patients with ankylosing spondylitis. Rheumatol Int 2019;39:1389-1396.

4. Sawacha Z, Carraro E, Del Din S, Guiotto A, Bonaldo L, Punzi L, et al. Biomechanical assessment of balance and posture in subjects with ankylosing spondylitis. J Neuroeng Rehabil 2012;9:63.
5. Dursun N, Sarkaya S, Ozdolap S, Dursun E, Zateri C, Altan L, et al. Risk of falls in patients with ankylosing spondylitis. J Clin Rheumatol 2015;21:76-80.

6. Inanır A, Okan S, Filiz B. Evaluation of postural stability and fall risk in patients with ankylosing spondylitis. Cukurova Med J 2013,38: 86-91.

7. D'Agostino MA, Olivieri I. Enthesitis. Best Pract Res Clin Rheumatol 2006;20:473-86.

8. Tolu S, Rezvani A, Hindioglu N, Kirez IE, Korkmaz M. Postural stability and the relationship with enthesitis in ankylosing spondylitis: A crosssectional study. Medicine Science 2019;8:613-9.

9. van der Linden S, Valkenburg HA, Cats A. Evaluation of diagnostic criteria for ankylosing spondylitis. A proposal for modification of the New York criteria. Arthritis Rheum 1984;27:3618.

10. Garrett $\mathrm{S}$, Jenkinson $\mathrm{T}$, Kennedy LG, Whitelock H, Gaisford P, Calin P. A new approach to defining disease status in ankylosing spondylitis: the Bath Ankylosing Spondylitis Disease Activity Index. J Rheumatol 1994;21:2286-91.

11. Akkoc Y, Karatepe AG, Akar S, Kirazli Y, Akkoc N. A Turkish version of the Bath Ankylosing Spondylitis Disease Activity Index: reliability and validity. Rheumatol Int $2005 ; 25: 280-84$.

12. Machado P, Landewe R, Lie E, Kvien TK, Braun J, Baker D, et al. Assessment of SpondyloArthritis international Society. Ankylosing Spondylitis Disease Activity Score (ASDAS): defining cut-off values for disease activity states and improvement scores. Ann Rheum Dis 2011;70: 47-53.

13. Calin A, Garrett S, Whitelock H, Kennedy LG, O'Hea J, Mallorie P, et al. A new approach to defining functional ability in ankylosing spondylitis: the development of the Bath Ankylosing Spondylitis Functional Index. J Rheumatol 1994;21: 2281-05.

14. Ozer HT, Sarpel T, Gulek B, Alparslan ZN. The Turkish version of the Bath Ankylosing Spondylitis Functional Index: reliability and validity. Clin Rheumatol 2005;24: 123-28.

15. Jenkinson TR, Mallorie PA, Whitelock HC, Kennedy LG, Garrett SL, Calin A. Defining spinal mobility in ankylosing spondylitis (AS). The Bath AS Metrology Index. J Rheumatol 2004;21:16948.

16. Doward LC, Spoorenberg A, Cook SA, Whalley D, Helliwell PS, Kay LJ, et al. 
Development of the ASQoL: a quality of life instrument specific to ankylosing spondylitis. Ann Rheum Dis 2003;2:20-26.

17. Duruöz MT, Doward L, Turan Y, Cerrahoglu L, Yurtkuran M, Calis M, et al. Translation and validation of the Turkish version of the Ankylosing Spondylitis Quality of Life (ASQOL) questionnaire. Rheumatol Int 2013;33:2717-22.

18. Ware JE, Sherbourne CD. The MOS 36-item short-form health survey (SF-36). I. Conceptual framework and item selection. Med Care 1992;30: 473-83.

19. Kocyigit H, Aydemir O, Olmez N, N Olmez, A Kisa Memis. Reliability and validity of the Turkish version of short-form-36 (SF-36). Turkish J Drugs Therap 1999;12:102-6.

20. Kornetti DL, Fritz SL, Chiu Y-P, Light KE, Velozo CA. Rating scale analysis of the Berg Balance Scale. Arch Phys Med Rehabil 2004;85:1128-35.

21. Duncan PW, Weiner DK, Chandler J, Studenski S. Functional reach: a new clinical measure of balance. J Gerontol 1990;45:192-7.

22. Podsiadlo D, Richardson S. The timed 'Up \& Go": a test of basic functional mobility for frail elderly persons. J Am Geriatr Soc 1991;39:142148.

23. Tinetti ME, Richman D, Powell L. Falls efficacy as a measure of fear of falling. J Gerontol1990;45:234-43.

24. Dorenbosch LH, Spoorenberg A, Van Tubergen A. Assessment of enthesitis in ankylosing spondylitis. Ann Rheum Dis 2003;62:127-32.

25. Onen F, Akar S, Birlik M, et al. Prevalence of Ankylosing spondylitis and related spondyloarthritides in an urban area of Izmir, Turkey. J Rheumatol. 2008;35:305-9.

26. Elolemy G, Aboughanima A, Ganeb S, Elziat H. Health-Related Quality of Life in Patients with Ankylosing Spondylitis: Relationship with
Disease-Related Variables. Curr Rheumatol Rev 2019

27. Laatiris A, Amine B, Ibn Yacoub Y, HajjajHassouni N. Enthesitis and its relationships with disease parameters in Moroccan patients with ankylosing spondylitis. Rheumatol Int 2012;32:723-7.

28. Murray HC, Elliott C, Barton SE, Murray A. Do patients with ankylosing spondylitis have poorer balance than normal subjects? Rheumatology 2000;39:497-500.

29. Gündüz OH, Özcan-Ekşi EE, Giray E, Yağci İ. What Impairs Balance in Ankylosing Spondylitis? Posture or Disease Activity? Arch Rheumatol 2017;32:221-226.

30. Batur BE, Karataş KG. Do Postural Changes Affect Balance in Patients with Ankylosing Spondylitis? J Rehabil Med 2017;49:437-440.

31. Lee JS, Suh KT, Kim JI, Goh TS. Analysis of sagittal balance of ankylosing spondylitis using spinopelvic parameters. J Spinal Disord Tech 2014;27:94-8.

32. Alkan H, Yildız N, Sarsan A, Atalay Simsir N, Sevinc HO, Topuz O, et al. Fall risk in patients with Ankylosing Spondylitis. Turk J Rheumatol 2013;28:109-116.

33. Demontis A, Trainito S, Del Felice A, Masiero $S$. Favorable effect of rehabilitation on balance in ankylosing spondylitis: a quasi-randomized controlled clinical trial. Rheumatol Int 2016;36:333-9.

34. Sivas F, Baskan BM, Inal E, Aktekin LA, Barça $\mathrm{N}$, Özoran $\mathrm{K}$, et al. The relationship between enthesitis indices and disease activity parameters in patients with ankylosing spondylitis. Clin Rheumatol 2009;28:259-264.

35. Heuft-Dorenbosch L, Spoorenberg A, van Tubergen A, Landewé $R$, van ver Tempel $H$, Mielants $\mathrm{H}$, et al. Assessment of enthesitis in ankylosing spondylitis. Ann Rheum Dis 2003;62:127-32. 